\title{
Melanin Production Inhibitors from the West African Cassipourea congoensis
}

\section{(ㄷ)(우우 $\Theta$}

\author{
Authors

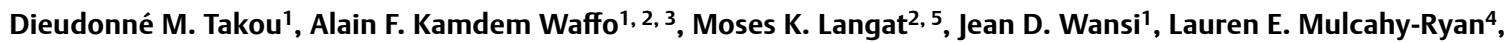 \\ Sianne L. Schwikkard ${ }^{4}$, Elizabeth I. Opara ${ }^{4}$, Eduard Mas-Claret ${ }^{2}$, Dulcie A. Mulholland ${ }^{2,3}$
}

\section{Affiliations}

1 Department of Chemistry, Faculty of Science, University of Douala, Douala, Cameroon

2 Department of Chemistry, Natural Products Research Group, Faculty of Engineering and Physical Sciences, University of Surrey, Guildford, United Kingdom

3 School of Chemistry and Physics, University of KwaZuluNatal, Durban, South Africa

4 School of Life Sciences, Pharmacy and Chemistry, Kingston University, London, Kingston, United Kingdom

5 Natural Capital and Plant Health Department, Jodrell Laboratory, Royal Botanic Gardens, Kew, Richmond, Surrey, United Kingdom

\section{Key words}

Cassipourea congoensis, rhizophoraceae, cycloartane triterpenoids, 26-hydroxy-3-keto-24-methylenecycloartan30-oic acid, 24-methylenecycloartan-3 $\beta$, 26, 30-triol, skin-lightening agents, tyrosinase inhibition and melanin inhibition

$\begin{array}{ll}\text { received } & 22.02 .2019 \\ \text { revised } & 07.08 .2019 \\ \text { accepted } & 26.08 .2019\end{array}$

Bibliography

DOI https://doi.org/10.1055/a-1006-2880

Published online: 2019

Planta Med Int Open 2019; 6: e50-e56

(c) Georg Thieme Verlag KG Stuttgart . New York

ISSN 2509-9264

\section{Correspondence}

Dr. Sianne Schwikkard

School of Life Sciences, Pharmacy and Chemistry

Kingston University

London

Kingston KT1 2EE

United Kingdom

Tel.: + 44/208/4176 634

s.schwikkard@kingston.ac.uk

$\circledast$

Supplementary Material for this article is available online at http://www.thieme-connect.de/products.

\section{ABSTRACT}

Cassipourea congoensis (syn. Cassipourea malosana) is used in African countries as a skin-lightening agent. Two previously unreported cycloartane triterpenoids, 26-hydroxy-3-keto-24methylenecycloartan-30-oic acid 1 and 24-methylenecycloartan-3 $\beta, 26,30$-triol 2 along with the known mahuannin B 3, 7-methoxymahuannin B 4, 7-methoxygeranin A 5, methyl3-(4-hydroxy-3-methoxyphenyl)-2E-propenoate, glycerol1-alkanoate, (E)-3-(4-hydroxy-3-methoxyphenyl)prop-2-enal 6, (-)-syringaresinol 7, and stigmast-5-en-3-O- $\beta$-D-glucoside, were isolated from the roots of $C$. congoensis. The crude extract and compounds $\mathbf{1}$ and $\mathbf{5}$ were found to inhibit the production of melanin at $10 \mu \mathrm{M}$ with low cytotoxicity validating the ethnomedicinal use of this plant.

\section{Introduction}

Several topical agents are available to treat hyperpigmentation and act at different levels of the melanogenesis pathway [1,2]. The most commonly used compounds are $p$-hydroquinone, corticosteroids, and mercurials [3]. The long-term use of these products may cause undesirable cutaneous or systemic side effects [3-5]. p-Hydroquinone was one of the earliest treatments for hyperpigmentation and remains the standard against which other treatments are measured $[2,6]$. The misuse of this compound as a skin- lightening agent, despite its sale being prohibited in many countries, is significant, although its use is associated with serious side effects, including irritant contact dermatitis and exogenous ochronosis $[3,5,7]$. We have previously reported the nontoxic melanin production inhibitors from the South African medicinal plant, Garcinia livingstonei T.Anderson (Clusiaceae), which is used ethnomedicinally for skin-lightening purposes [8] and we now report the investigation of a second species used for its skin-lightening properties, Cassipourea congoensis R Br. ex DC (Rhizophoraceae). p-Hydroqui- 
none inhibits tyrosinase, preventing the conversion of tyrosine to dihydroxyphenylalanine, a precursor to melanin. Thus, tyrosinase is a target in the search for a medically acceptable, natural, skinlightening agent for medical or cosmetic purposes.

C. congoensis is a plant endemic to Africa, growing as a shrub but sometimes a small tree of 3-5 m high on forest river banks. It is distributed across Senegal to Nigeria and easterly across the Congo basin to Uganda, Tanzania, and Malawi [9]. C. congoensis was previously named Cassipourea africana Benth. or Weihea africana (Benth.) Oliv. [10]. The fruits of $C$. congoensis are used in Nigeria as a substitute for tamarind (Tamarindus indica) L. (Fabaceae) in preparing local pap, a maize meal, and its nutritional content has been studied [11]. It is also regarded as a synonym of Cassipourea malosana (Baker) Alston (Rhizophoraceae) that is restricted to eastern Democratic Republic of Congo, Ethiopia, and south to South Africa. C. malosana is also reported to be closely related to, and often confused with, Cassipourea flanaganii Schinz (Alston) (Rhizophoraceae) and C. flanaganii is, used traditionally in South Africa as a skin-lightening agent [12]. The Cassipourea genus is reported to yield sulfur-containing compounds that include gerrardine [13], guinesine $B$, and guinesine $C$ [14], sulfur-containing amides that include cassipoureamide $A$ and $B$ [15], euphane and lupane type triterpenoids [16, 17], flavonols, flavonol glycoside and biflavonoids [18-20] and bioactive monocyclic diterpenoids [16] . Extractives from the stem bark of C. malosana, including 2 novel flavan dimers, were tested against human ovarian cancer cells and showed very little activity [21].

Two previously unreported cycloartane triterpenoids, 26-hydroxy-3-keto-24-methylenecycloartan-30-oic acid 1 and 24-methylenecycloartan-3 $3,26,30$-triol 2 along with the known mahuannin B 3, 7-methoxymahuannin B 4, 7-methoxygeranin A 5, methyl-3-(4-hydroxy-3-methoxyphenyl)-2E-propenoate, glycerol-1-alkanoate, (E)-3-(4-hydroxy-3-methoxyphenyl) prop-2-enal 6, (-)-syringaresinol 7, and stigmast-5-en-3-O- $\beta$-D-glucoside, were isolated from the roots of $C$. congoensis. The compounds 1-7, together with the crude extract, were screened for cytotoxicity against melanocytes (human primary epidermal melanocytes, ATCC) as well as for tyrosinase and melanin inhibitory activity. The crude extract and compounds $\mathbf{1}$ and $\mathbf{5}$ were subsequently found to inhibit the production of melanin at both 10 and $100 \mu \mathrm{M}$ with low cytotoxicity validating the ethnomedicinal use of this plant. No previous studies have assessed the cytotoxicity, the effect on inhibition of tyrosinase, or melanin inhibitory activity of $C$. congoensis.

\section{Results and Discussion}

In the present study we report the isolation of 2 new cycloartane tritepernoids, 26 hydroxy-3-keto-24-methylenecycloartan-30-oic, acid 1 and 24-methylenecycloartan-3ß,26,30-triol 2 together with the known proanthocyanidins, mahuannin B 3 [19], 7-methoxymahuannin B 4 [19], 7-methoxygeranin A 5[20], methyl-3-(4-hydroxy-3-methoxyphenyl)-2E-propenoate, glycerol-1-alkanoate, (E)-3-(4-hydroxy-3-methoxyphenyl)prop-2-enal 6, (-)-syringaresinol 7, and stigmast-5-en-3-O- $\beta$-D- glucoside and screening for tyrosinase inhibitory activity and the subsequent inhibition of melanin formation. These compounds were isolated from the roots of
C. congoensis. Both the roots and the bark of the plant are used as skin-lightening preparations.

Compound 1 was isolated as a white amorphous powder and the ESI( + )-HRMS indicated a molecular formula of $\mathrm{C}_{31} \mathrm{H}_{48} \mathrm{O}_{4}$ and 8 degrees of unsaturation. The IR spectrum indicated the presence of a ketone group, a carboxylic acid and double bonds, shown by absorption bands at 3438, 1730, 1707, and $1621 \mathrm{~cm}^{-1}$. The ${ }^{1} \mathrm{H}$ and ${ }^{13} \mathrm{C}$ NMR resonances for compound $\mathbf{1}$ were in close agreement with those of the reported 3-oxo-24-methylene cycloartan-26-ol $[22,23]$. The ${ }^{13} \mathrm{C}$ NMR spectrum indicated the presence of a ketone $\left(\delta_{C} 216.9\right)$ and a carboxylic acid group carbon resonance $\left(\delta_{C} 181.1\right)$. The ${ }^{1} \mathrm{H}$ NMR spectrum showed a shielded pair of doublets $\left(\delta_{\mathrm{H}} 0.87\right.$, $\mathrm{d}, \mathrm{J}=4.4 \mathrm{~Hz} ; 0.50, \mathrm{~d}, \mathrm{~J}=4.4 \mathrm{~Hz}$ ) characteristic of the $2 \mathrm{H}-19$ cyclopropane ring protons. The corresponding $\mathrm{C}-19$ resonance $\left(\delta_{\mathrm{C}} 29.8\right)$ showed correlations in the HMBC spectrum with the $\mathrm{H}-8\left(\delta_{\mathrm{H}} 1.83\right.$, $\mathrm{m})$ and $\mathrm{H}-5\left(\delta_{\mathrm{H}} 1.70\right)$ resonances. The $\mathrm{H}-5$ resonance showed correlations with the $\mathrm{C}-3$ keto group carbon resonance and the corresponding $C-5$ resonance with the $3 \mathrm{H}-28\left(\delta_{\mathrm{H}} 1.09, \mathrm{~s}\right)$ and $3 \mathrm{H}-29\left(\delta_{\mathrm{H}}\right.$ 1.02 , s) methyl group proton resonances. The $\mathrm{H}-8$ resonance showed a correlation with the carboxylic acid group carbon resonance, and hence this group was placed at $\mathrm{C}-30$. The $\mathrm{H}-8$ resonance also showed a correlation with the $C-13$ resonance $\left(\delta_{C} 47.9\right)$, which, in turn, showed correlations with the $3 \mathrm{H}-18\left(\delta_{\mathrm{H}} 1.05\right)$ and $\mathrm{H}-20\left(\delta_{\mathrm{H}}\right.$ 1.48 ) resonances. The $\mathrm{H}-20$ resonance showed coupling in the COSY spectrum with the $3 \mathrm{H}-21$ doublet resonance $\left(\delta_{H} 0.92, d\right.$, $\mathrm{J}=6.3 \mathrm{~Hz}$ ).

The ${ }^{13} \mathrm{C}$ NMR spectrum showed a hydroxymethylene carbon resonance $\left(\delta_{C} 66.1\right)$, which was assigned as $C-26$, with corresponding nonequivalent oxymethylene protons seen as a pair of double doublets $\left(\delta_{\mathrm{H}} 3.56, \mathrm{dd}, \mathrm{J}=7.0,10.4 \mathrm{~Hz} ; 3.51\right.$, $\left.\mathrm{dd}, \mathrm{J}=10.4,7.0 \mathrm{~Hz}\right)$. The $\mathrm{H}$-26 resonances were seen to be coupled in the COSY spectrum with each other and the $\mathrm{H}-25$ resonance $\left(\delta_{\mathrm{H}} 2.36\right.$, sextet, $\left.\mathrm{J}=7.0 \mathrm{~Hz}\right)$ and this resonance was seen to be coupled to the $3 \mathrm{H}-27$ doublet $\left(\delta_{\mathrm{H}}\right.$ $1.04, \mathrm{~d}, \mathrm{~J}=7.0 \mathrm{~Hz}$ ) and long range coupled to a pair of vinyl methylene protons $\left(\delta_{H} 4.88, s ; 4.82, s\right)$ assigned as the $2 \mathrm{H}-31$ protons. The $\mathrm{HMBC}$ spectrum showed correlations between the corresponding C-31 resonance $\left(\delta_{C} 109.9\right)$ and the $\mathrm{H}-25$ resonance and between the $\mathrm{C}-24$ resonance $\left(\delta_{\mathrm{C}} 152.0\right)$ and the $2 \mathrm{H}-26,3 \mathrm{H}-27$ and $2 \mathrm{H}-22$ resonances. Based on the above spectral data, compound 1 was identified as 26-hydroxy-3-oxo-24-methylene cycloartan-30-oic acid. This compound has not been reported previously.

The IR spectrum of compound $\mathbf{2}$ showed the presence of a hydroxy group and double bond with absorption bands at 3432 and $1623 \mathrm{~cm}^{-1}$, respectively. The ${ }^{1} \mathrm{H}$ and ${ }^{13} \mathrm{C}$ NMR resonances for compound $\mathbf{2}$ differed slightly from those of compound $\mathbf{1}$ as the ketone and carboxylic acid carbon resonances observed in the ${ }^{13} \mathrm{C}$ NMR spectrum of $\mathbf{1}$ were absent in $\mathbf{2}$ but 2 new oxygenated carbon resonances were present at $\delta_{\mathrm{C}} 78.9(\mathrm{CH})$ and $\delta_{\mathrm{C}} 64.8\left(\mathrm{CH}_{2}\right)$. Correlations were observed in the $\mathrm{HMBC}$ spectrum between the $3 \mathrm{H}-28\left(\delta_{\mathrm{H}} 0.81\right.$, s), the $3 \mathrm{H}-29\left(\delta_{\mathrm{H}} 0.97, \mathrm{~s}\right)$, and $\mathrm{H}-5\left(\delta_{\mathrm{H}} 1.33\right)$ resonances and the resonance at $\delta_{C} 78.9$, indicating the presence of a hydroxy group at $\mathrm{C}-3$. The hydroxy group at $\mathrm{C}-3$ was assigned as $\beta$ due to the chemical shift of $\delta_{C} 78.9$, typical for a $3 \beta$-substituted hydroxy group as opposed to $\delta_{C} 76.8$ when the 3 -hydroxy group is in the $\alpha$-position [22]. This assignment was confirmed by correlations seen in the 
NOESY spectrum between the $\mathrm{H}-3 / \mathrm{H}-5$ and $\mathrm{H}-3 / 3 \mathrm{H}-28$ resonances. Instead of the $\mathrm{C}-30$ methyl group being oxidized to a carboxylic acid as in $\mathbf{1}$, it was oxidized to an oxymethylene $\left(\delta_{C} 68.2\right)$ group in $\mathbf{2}$. The $\mathrm{C}-30$ resonance showed a correlation in the $\mathrm{HMBC}$ spectrum with the $\mathrm{H}-8$ resonance $\left(\delta_{\mathrm{H}} 1.56, \mathrm{~m}\right)$. The side chain remained the same as for compound $\mathbf{1}$. This compound was found to be the previously unreported 24-methylenecycloartan-3 $\beta, 26,30$-triol.

C. congoensis is closely related to and is often confused with C. flanaganii, a plant used in South Africa as a skin-lightening agent [12]. The widespread use of this plant and its related species for skin-lightening purposes make the investigation into both its efficacy and safety of importance. Tyrosinase is a key enzyme in the production of melanin as it catalyzes the rate-limiting step in the production of this pigment. The inhibition of tyrosinase by the test compounds would indicate that tyrosinase inhibition may be one of the mechanisms by which these compounds operate and it would give a good indication of which compounds are responsible for the skin-lightening effect of the plant extract. All compounds tested as well as the crude extract showed significant inhibition of tyrosinase $(\mathrm{p}<0.01)$ when compared to the negative controls (PBS and DMSO). However, the effect of the crude extract was greater than that of any of the individual compounds tested. Furthermore, unlike the isolated compounds, the inhibitory effect of the crude extracts on tyrosinase exceeded that of the positive control, $p$-hydroquinone, which is also used as a skin-lightening agent, ( $\mathbf{F i g}$. 1). Further characterization showed that the crude extract and a selection of its isolated compounds (compounds $\mathbf{1}$ and $\mathbf{5}$, selected based on their very differing levels of potency on tyrosinase activity) are significantly $(p<0.001)$ inhibiting the production of melanin in the human primary epidermal melanocytes, compared to the negative controls, over both 24 and 48 h at the concentrations used ( $>$ Fig. 2). Their effect, however, did not appear to be time-dependent. There

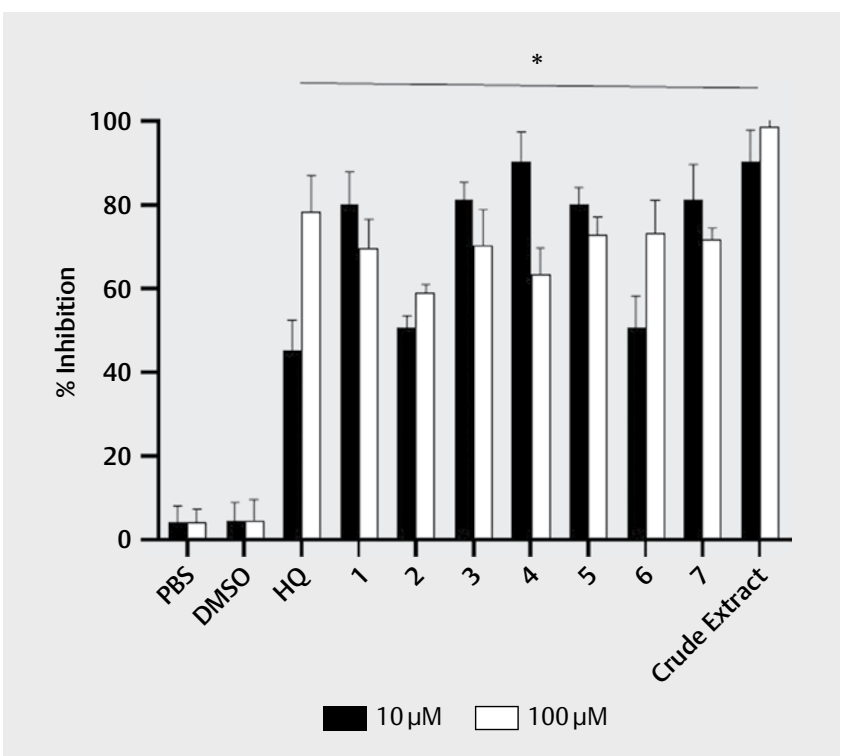

- Fig. 1 The effect of compounds 1-7 and HQ (p-hydroquinone) at 10 and $100 \mu \mathrm{M}$ and crude extract at $1 \mathrm{and} 10 \mathrm{mg} / \mathrm{mL}$ of $C$. congoensis on tyrosinase activity. ${ }^{*} p<0.001$ compared to the negative controls. Each data point represents $n=3$ and is representative of 3 independent experiments. was no significant increase in melanin production in either the crude extract or isolated compounds when compared to $p$-hydroquinone ( $p \leq 0.1$ ), thus demonstrating the inhibitory potential of both the crude extract and the compounds. Interestingly, the extent of inhibition of melanin synthesis did not mirror that of tyrosinase activity for the crude extract and compounds $\mathbf{1}$ and $\mathbf{5}$. For the latter compound, the inhibition of melanin was far greater than expected based on its effect on tyrosinase activity which was relatively low compared to that of the crude extract and compound 1 . This result may suggest that the crude extract's, and some of its isolated compounds', mechanism of action may also involve their inhibition of other enzymes involved in melanin synthesis such as tyrosinase related proteins 1 and 2 (TYP-1 and TRP-2) [24]. To shed further light on how these compounds behave in relation to melanin synthesis their effect on the activities of tyrosinase, TRP- 1 and TRP-2 in melanocytes needs to be investigated.

Cytotoxicity towards melanocytes was determined using a neutral red assay ( $\mathbf{F i g}$. $\mathbf{3 a - c}$ ) over 3 independent experiments $(n=3)$.
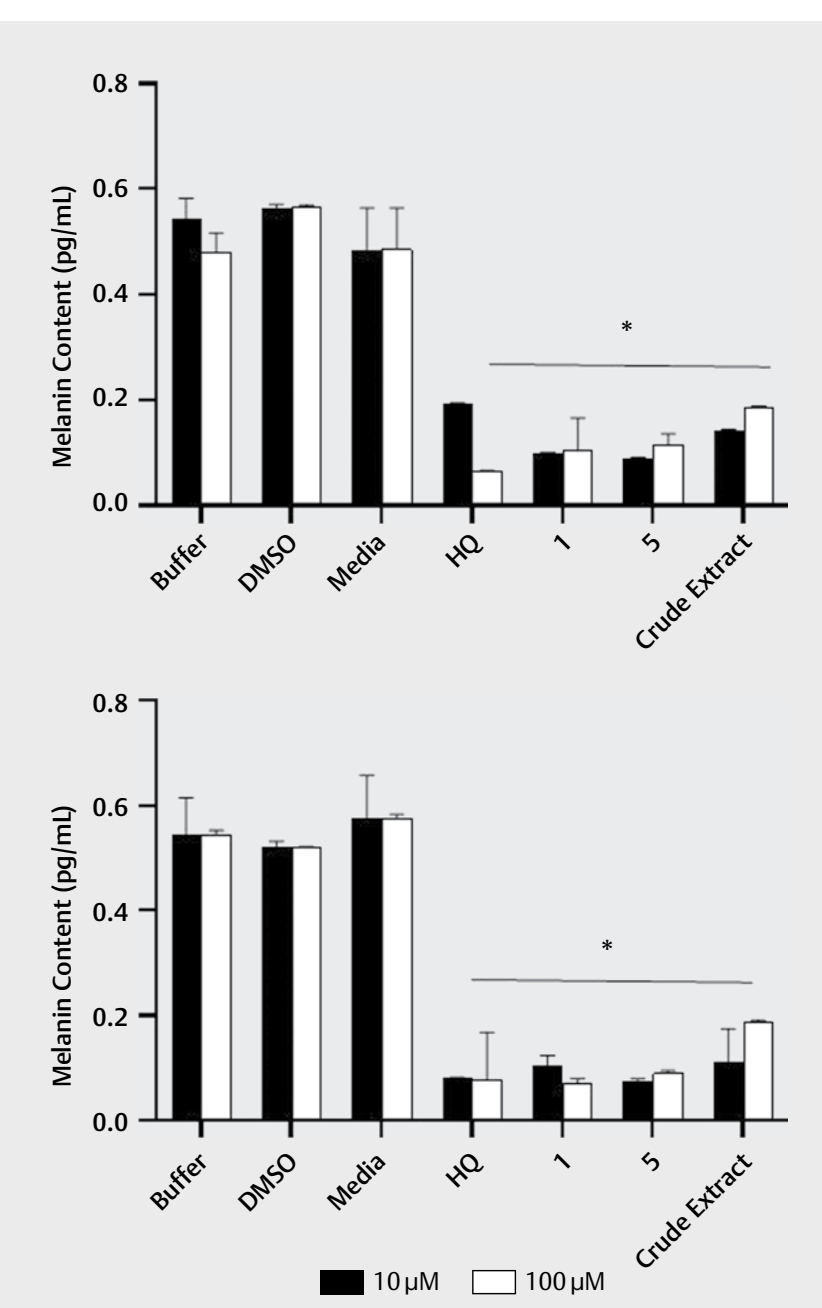

- Fig. 2 The effect of compounds $\mathbf{1}$ and $\mathbf{5}$ at 10 and $100 \mu \mathrm{M}$ and crude extract at 1 and $10 \mathrm{mg} / \mathrm{mL}$ of $C$. congoensis for $24 \mathrm{~h}$ (top) and $48 \mathrm{~h}$ (bottom) on melanin content in primary melano-

cytes. ${ }^{*} \mathrm{p}<0.001$ compared to the negative controls. Each data point represents $n=3$ and is representative of 3 independent experiments. 

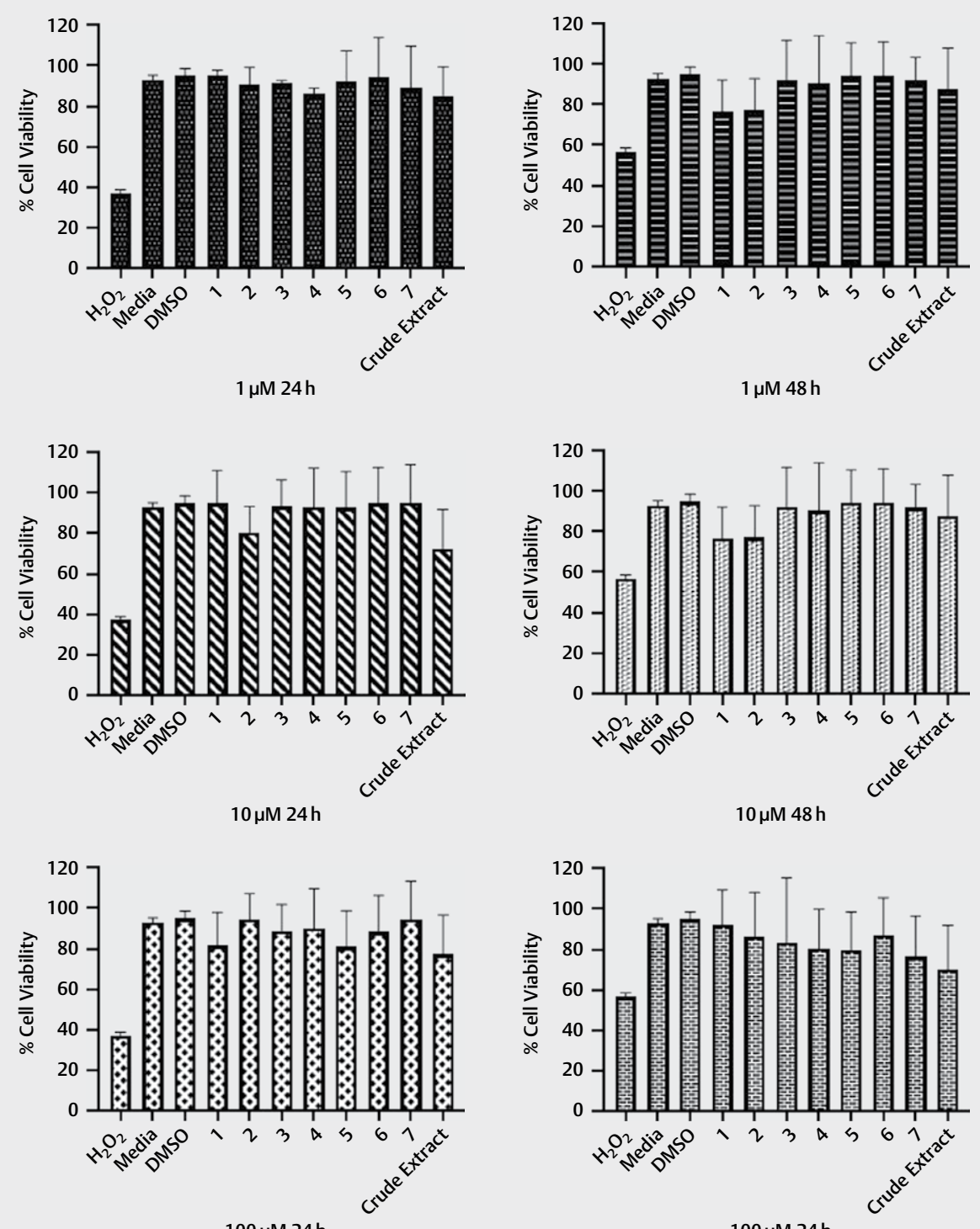

$100 \mu \mathrm{M} 24 \mathrm{~h}$

$100 \mu \mathrm{M} 24 \mathrm{~h}$

- Fig. 3 Percentage viability of human primary epidermal melanocytes exposed to crude extracts of 1 and $10 \mathrm{mg} / \mathrm{mL}$ and compounds $1 \mu \mathrm{M}$ a, $10 \mu \mathrm{M} \mathrm{b}$, and $100 \mu \mathrm{M} \mathrm{c}$ from C. congoenesis for 24 and $48 \mathrm{~h}$. No significant cytotoxicity was observed when compared to the negative controls $(p<0.05)$. Each data point represents $n=3$ and is representative of 3 independent experiments.

No significant cytotoxicity was detected for the test compounds or crude extract relative to the negative controls at a confidence limit of $95 \%$ (media, and vehicle control, $p<0.05$ ). The crude extract did show a greater cytotoxicity than the individual compounds isolated.

The results of this study show that the crude extract (as used for skin-lightening purposes) as well as the isolates studied had no significant cytotoxicity when compared to the negative controls while still showing significant inhibition of tyrosinase and, in the case of the crude extracts and compounds $\mathbf{1}$ and $\mathbf{5}$, melanin production by primary melanocytes. Overall, this result suggests this plant, and its compounds, may be a good alternative to preparations containing $p$-hydroquinone.

Spectra for compounds $\mathbf{1}$ and $\mathbf{2}$ are available as Supporting Information.

\section{Materials and Methods}

\section{General experimental procedures}

Optical rotations were measured on a JASCO P-1020 polarimeter. ECD spectra were obtained on an Applied Photophysics Chirascan $\mathrm{CD}$ spectrometer using a 1-mm cell and acetonitrile as the solvent. FTIR spectra were recorded using a Perkin-Elmer (2000) spectrometer. 1D and 2D NMR spectra were recorded in $\mathrm{CDCl}_{3}$ on a $500 \mathrm{MHz}$ Bruker AVANCE NMR instrument at room temperature. Chemical shifts $(\delta)$ are expressed in ppm and were referenced against the solvent resonances at 7.26 and $77.23 \mathrm{ppm}$ for ${ }^{1} \mathrm{H}$ and ${ }^{13} \mathrm{C}$ NMR spectra, respectively. ESI(+)-HRMS mass spectra were recorded on a Bruker MicroToF mass spectrometer using an Agilent 1100 HPLC to introduce samples (University of Oxford). Column chromatogra- 

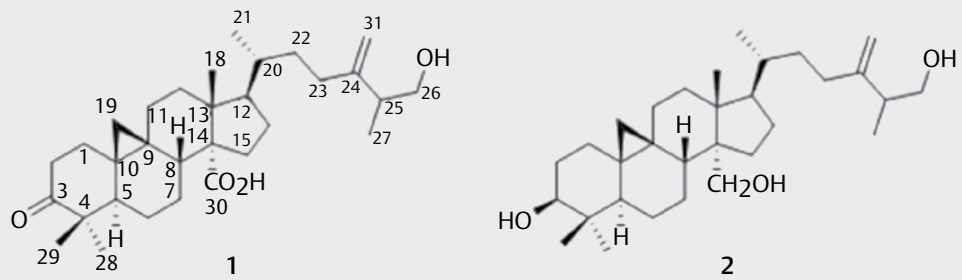

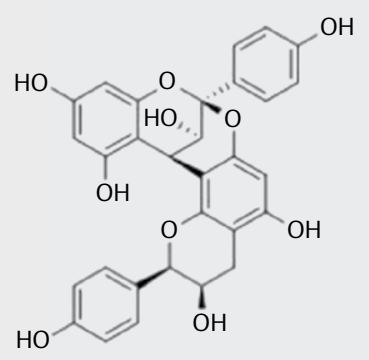

3<smiles>COc1cc(/C=C/C=O)ccc1O</smiles>

6

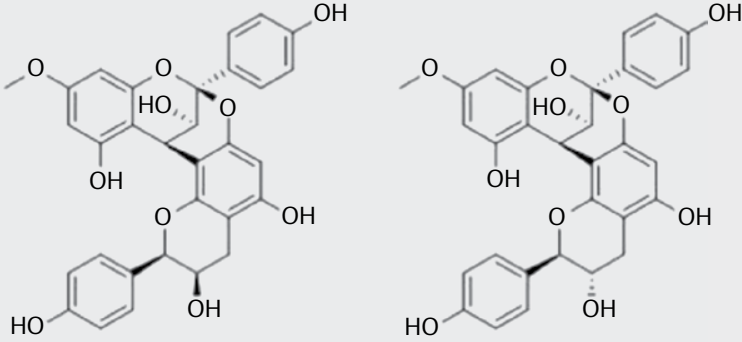

5

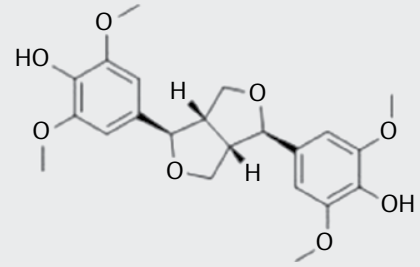

Fig. 4 Structures of compounds 1-7.

phy was done using $\mathrm{SiO}_{2}$ packed to 4- or 1-cm diameter gravity columns. TLC was done on aluminum-backed precoated $\mathrm{SiO}_{2}$ plates (Merck 9385) visualized using anisaldehyde spray reagent.

\section{Plant material}

The roots of $C$. congoensis were collected by Mr. Nana Victor in November 2010 at Mbalmayo, southern Cameroon. A voucher specimen (1773SRF/CAM) was deposited at the National Herbarium, Yaoundé, Cameroon.

\section{Extraction and isolation of compounds from C. congoensis}

The powdered root of $C$. congoensis $(1.3 \mathrm{~kg})$ was extracted successively with refluxing $\mathrm{CH}_{2} \mathrm{Cl}_{2}$ and $\mathrm{MeOH}$ for $48 \mathrm{~h}$ each. The solvents were evaporated under reduced pressure using a rotary evaporator (Büchi type R-205) to give brownish extracts of $16.2 \mathrm{~g}$ and $47.2 \mathrm{~g}$ of extract respectively. The $\mathrm{CH}_{2} \mathrm{Cl}_{2}$ extract was separated using column chromatography over silica gel (Merck 9385) eluting with n-hexane with increasing amounts of $\mathrm{CH}_{2} \mathrm{Cl}_{2}$. Once $100 \% \mathrm{CH}_{2} \mathrm{Cl}_{2}$ had been reached, a step gradient elution using methanol was used to yield several fractions ( $75 \mathrm{~mL}$ each). Combined fractions 32-39 were purified using a n-hexane- $\mathrm{CH}_{2} \mathrm{Cl}_{2}(1: 1)$ system to give 26-hydroxy-3-oxo-24-methylene cycloartan-30-oic acid 1 (10.5 mg). Purification of combined fractions 66-69 using a n-hexane- $\mathrm{CH}_{2} \mathrm{Cl}_{2}$ system (1:1) gave 24-methylenecycloartan-3ß,26,30-triol 2
$(12.5 \mathrm{mg})$ whereas purification of combined fractions 105-110 using $100 \% \mathrm{CH}_{2} \mathrm{Cl}_{2}$ gave mahuannin $\mathrm{B} 3(10.3 \mathrm{mg})$, 7-methoxymahuannin 4 (17.5 mg), and glycerol 1-alkanoate. The $\mathrm{MeOH}$ extract $(47.2 \mathrm{~g})$ was separated using column chromatography over silica gel using $\mathrm{CH}_{2} \mathrm{Cl}_{2}$-EtOAc mixtures of increasing polarity to yield several fractions ( $75 \mathrm{~mL}$ each) that were combined following analytical TLC analysis. Fractions 47-59, 126-131, and 139-154 were purified using $\mathrm{CH}_{2} \mathrm{Cl}_{2}$-EtOAC (3:1), $\mathrm{CH}_{2} \mathrm{Cl}_{2}$-EtOAC (1:5), and EtOAC $100 \%$ to give 7-methoxygeranin A 5 (12.8 mg), (E)-3-(4-hydroxy3-methoxyphenyl)prop-2-enal, 6 (15.2 mg), and (-)-syringaresinol $7(18.2 \mathrm{mg})$, respectively. Stigmast-5-en-3-O- $\beta$-D-glucoside (25.6 mg) was obtained from combined fractions 139-154 alongside 1. Structures are shown in > Fig. 4.

26-Hydroxy-3-oxo-24-methylenecycloartan-30-oic acid (1):

White amorphous powder; ( $10.5 \mathrm{mg},>98 \%$ pure; from NMR) $[\alpha]^{25}+19$ (c 0.0270, $\mathrm{CHCl}_{3}$ ); IR (neat) $v_{\max } 3438,2957,2853,1707$, $1621 \mathrm{~cm}^{-1}$; ESI(+)-HRMS m/z 507.3447 [M+ Na] ${ }^{+}$(calcd for $\mathrm{C}_{31} \mathrm{H}_{48} \mathrm{O}_{4} \mathrm{Na}$, 507.3450); see $>$ Table 1 for ${ }^{1} \mathrm{H}$ NMR $\left(500 \mathrm{MHz}, \mathrm{CDCl}_{3}\right)$ and ${ }^{13} \mathrm{C} \mathrm{NMR}\left(125 \mathrm{MHz}, \mathrm{CDCl}_{3}\right)$ data.

24-Methylenecycloartan-3 $\beta, 26,30$-triol (2)

White amorphous powder; ( $12.5 \mathrm{mg},>90 \%$ pure; from NMR) $[\alpha]^{25} \mathrm{D}+19.5$ (c 0.0350, $\mathrm{CHCl}_{3}$ ); IR (neat) $\mathrm{v}_{\max } 3432,2957,2853$, $1623 \mathrm{~cm}^{-1}$; ESI(+)-HRMS m/z $495.3793[\mathrm{M}+\mathrm{Na}]^{+}$(calcd for $\mathrm{C}_{31} \mathrm{H}_{52} \mathrm{O}_{3} \mathrm{Na}$, 495.3814); see $>$ Table 1 for ${ }^{1} \mathrm{H}$ NMR $\left(500 \mathrm{MHz}, \mathrm{CDCl}_{3}\right.$ and ${ }^{13} \mathrm{C} \mathrm{NMR}\left(125 \mathrm{MHz}, \mathrm{CDCl}_{3}\right)$ data. 
- Table $1{ }^{1} \mathrm{H}$ and ${ }^{13} \mathrm{C} \mathrm{NMR}$ data for compounds $\mathbf{1}$ and $\mathbf{2}\left(\mathrm{CDCl}_{3}, 500 \mathrm{MHz}\right.$ for ${ }^{1} \mathrm{H}$ NMR and $125 \mathrm{MHz}$ for ${ }^{13} \mathrm{C}$ NMR spectra).

\begin{tabular}{|c|c|c|c|c|}
\hline \multicolumn{3}{|c|}{ Compound 1} & \multicolumn{2}{|c|}{ Compound 2} \\
\hline No & $\delta_{\mathrm{c}}$ & $\delta_{\mathrm{H}}(/$ in $\mathrm{Hz})$ & $\delta_{\mathrm{c}}$ & $\delta_{\mathrm{H}}(U$ in $\mathrm{Hz})$ \\
\hline $1 \alpha$ & 33.5 & $1.87 \mathrm{~m}$ & 32.3 & $1.60 \mathrm{~m}$ \\
\hline$\beta$ & & $1.61 \mathrm{~m}$ & & $1.26 \mathrm{~m}$ \\
\hline $2 \alpha$ & 37.5 & $2.72 \mathrm{dt}(6.2,15.0)$ & 30.4 & $1.77 \mathrm{~m}$ \\
\hline$\beta$ & & $2.31 \mathrm{dt}(4.4,15.0)$ & & $1.58 \mathrm{~m}$ \\
\hline 3 & 216.9 & - & 78.9 & $\begin{array}{l}3.28 \mathrm{dd} \\
(4.3,11.1)\end{array}$ \\
\hline 4 & 50.1 & - & 40.7 & - \\
\hline 5 & 47.8 & $1.70 \mathrm{~m}$ & 47.5 & $1.33 \mathrm{~m}$ \\
\hline $6 \alpha$ & 21.0 & $1.49 \mathrm{~m}$ & 21.6 & $1.63 \mathrm{~m}$ \\
\hline$\beta$ & & $1.01 \mathrm{~m}$ & & $0.80 \mathrm{~m}$ \\
\hline $7 \alpha$ & 28.4 & $2.23 \mathrm{~m}$ & 27.5 & $1.93 \mathrm{~m}$ \\
\hline$\beta$ & & $1.35 \mathrm{~m}$ & & $1.46 \mathrm{~m}$ \\
\hline 8 & 45.4 & $1.83 \mathrm{~m}$ & 48.9 & $1.56 \mathrm{~m}$ \\
\hline 9 & 20.5 & - & 19.8 & - \\
\hline 10 & 27.7 & - & 26.5 & - \\
\hline $11 \alpha$ & 29.6 & $2.15 \mathrm{~m}$ & 27.2 & $1.91 \mathrm{~m}$ \\
\hline$\beta$ & & $1.40 \mathrm{~m}$ & & \\
\hline $12 \alpha$ & 33.8 & $1.86 \mathrm{~m}$ & 32.4 & $1.59 \mathrm{~m}$ \\
\hline$\beta$ & & $1.71 \mathrm{~m}$ & & $1.57 \mathrm{~m}$ \\
\hline 13 & 47.9 & - & 46.2 & - \\
\hline 14 & 63.0 & - & 54.2 & - \\
\hline $15 \alpha$ & 31.5 & $2.18 \mathrm{~m}$ & 28.1 & $1.91 \mathrm{~m}$ \\
\hline$\beta$ & & $1.28 \mathrm{~m}$ & & $1.44 \mathrm{~m}$ \\
\hline $16 \alpha$ & 27.0 & $1.53 \mathrm{~m}$ & 27.7 & $1.95 \mathrm{~m}$ \\
\hline$\beta$ & & $1.13 \mathrm{~m}$ & & $1.12 \mathrm{~m}$ \\
\hline 17 & 52.5 & $1.52 \mathrm{~m}$ & 52.5 & $1.60 \mathrm{~m}$ \\
\hline 18 & 18.0 & $1.11 \mathrm{~s}$ & 19.5 & $1.05 \mathrm{~s}$ \\
\hline $19 \mathrm{~A}$ & 29.8 & $0.87 \mathrm{~d}(4.0)$ & 30.7 & $0.59 \mathrm{~d}(4.0)$ \\
\hline B & & $0.50 \mathrm{~d}(4.0)$ & & $0.38 \mathrm{~d}(4.0)$ \\
\hline 20 & 35.8 & $1.48 \mathrm{~m}$ & 36.4 & $1.44 \mathrm{~m}$ \\
\hline 21 & 18.6 & $0.92(6.3)$ & 18.6 & $0.90 \mathrm{~d}(6.3)$ \\
\hline $22 \alpha$ & 34.8 & $1.60 \mathrm{~m}$ & 35.1 & \\
\hline$\beta$ & & $1.18 \mathrm{~m}$ & & $1.16 \mathrm{~m}$ \\
\hline $23 \alpha$ & 31.2 & $2.10 \mathrm{~m}$ & 31.4 & $2.11 \mathrm{~m}$ \\
\hline$\beta$ & & $1.85 \mathrm{~m}$ & & $1.88 \mathrm{~m}$ \\
\hline 24 & 152.0 & - & 152.2 & - \\
\hline 25 & 42.7 & 2.36 sextet (6.5) & 42.8 & $2.36 \mathrm{~m}$ \\
\hline $26 \mathrm{~A}$ & 66.1 & $3.56 \mathrm{dd}(7.0,10.4)$ & 66.1 & $\begin{array}{l}3.55 \mathrm{dd} \\
(7.0,10.4)\end{array}$ \\
\hline B & & $3.51 \mathrm{dd}(10.4,7.0)$ & & $\begin{array}{l}3.51 \mathrm{dd} \\
(10.4,7.0) \\
\end{array}$ \\
\hline 27 & 16.6 & $1.04 \mathrm{~d}(7.0)$ & 16.6 & $1.05 \mathrm{~d}(7.0)$ \\
\hline 28 & 22.4 & $1.02 \mathrm{~s}$ & 14.2 & $0.81 \mathrm{~s}$ \\
\hline 29 & 21.1 & $1.09 \mathrm{~s}$ & 25.6 & $0.97 \mathrm{~s}$ \\
\hline \multirow[t]{2}{*}{30} & 181.1 & - & 64.8 & $3.83 \mathrm{~d}(11.8)$ \\
\hline & & & & $3.68 \mathrm{~d}(11.8)$ \\
\hline \multirow[t]{2}{*}{31} & 109.9 & $4.88 \mathrm{~s}$ & 109.8 & $4.87 \mathrm{~s}$ \\
\hline & & $4.82 \mathrm{~s}$ & & $4.82 \mathrm{~s}$ \\
\hline
\end{tabular}

\section{Pharmacological assays}

Cell culture

Human primary epidermal melanocytes (ATCC) were cultured in Dermal Cell Basal Media (ATCC) supplemented with Adult Melanocyte Growth Kit Components and $2 \%$ penicillin-streptomycin-amphorectin B Solution (ATCC) and were grown as per manufacturer's instructions. On reaching $90 \%$ confluency, cells were passaged once prior to plating for cell culture experimentation. Positive controls, p-hydroquinone (purity $>99 \%$ ) and hydrogen peroxide (30 wt \% in water) used were purchased from Sigma-Aldrich.

Effect of $C$. congoensis crude extract and compounds on the viability of human primary epidermal melanocytes Compounds were resuspended from a stock solution (DMSO, $>99.7 \%$, Sigma-Aldrich) in $16 \mathrm{nM} \mathrm{K}_{3} \mathrm{PO}_{4}$ buffer (both from Sigma-Aldrich) at concentrations of 1,10 , and $100 \mu \mathrm{M}$. The crude extract was tested at concentrations of $1 \mathrm{mg} / \mathrm{mL}$ and $10 \mathrm{mg} / \mathrm{mL}$. Human primary epidermal melanocytes were plated in 96-well plates at a concentration of $1 \times 10^{5}$ cells/well. Following a $24-\mathrm{h}$ incubation, cells were treated with respective concentrations of compound and crude extracts (as above), as well as DMSO (the final concentration of DMSO \pm cells was $0.1 \%$ ), hydrogen peroxide ( $30 \mathrm{wt} \%$ in water), which was used as the positive control and media alone and further incubated for $24 \mathrm{~h}$ and $48 \mathrm{~h}$ to determine the extent of any toxicity over time. Neutral red (Sigma-Aldrich) was dissolved in water at a concentration of $3.3 \mu \mathrm{g} / \mathrm{mL}$. Cell culture media with compound or crude extract was removed from cells and $20 \mu \mathrm{L}$ neutral red solution was added to cells. Following a 2 -h incubation at $37^{\circ} \mathrm{C}$, the neutral red solution was removed and cells rinsed with DPBS. Two hundred microliters of a solution containing $1 \%$ acetic acid in $50 \%$ $\mathrm{EtOH} /$ deionized $\mathrm{H}_{2} \mathrm{O}$ was added to solubilize the dye. Following a 20-min incubation, supernatants were read using a Tecan Infinate Pro 200 plate reader at $540 \mathrm{~nm}$ and the cell viability determined.

\section{Effect of $C$. congoensis crude extract and compounds on} tyrosinase activity

The tyrosinase assay used is one previously described by Chou et al. [25]. Two hundred ten microliters of L-Dopa ( $>98 \%$, SigmaAldrich) was dissolved in $167 \mathrm{M} \mathrm{K}_{3} \mathrm{PO}_{4}$ buffer and incubated at $25^{\circ} \mathrm{C}$ for $10 \mathrm{~min}$ with $7.5 \mu \mathrm{L}$ of crude extract ( 1 and $10 \mathrm{mg} / \mathrm{mL}$ ) each compound $\left(10\right.$ and $100 \mu \mathrm{M}$ ), DMSO $0.1 \%, 16 \eta \mathrm{M} \mathrm{K}_{3} \mathrm{PO}_{4}$ buffer (the negative control and blank, respectively) or $p$-hydroquinone ( $>99 \%$, Sigma-Aldrich) ( 10 or $100 \mu \mathrm{M})$ (the positive control as $p$-hydroquinone is a known inhibitor of tyrosinase) [26], plus $7.5 \mu \mathrm{L}$ of tyrosinase (mushroom, lyophilized powder, $\geq 1000 \mathrm{unit} / \mathrm{mg}$ solid, Sigma-Aldrich) (or $20 \mathrm{mM} \mathrm{K}_{3} \mathrm{PO}_{4}$ buffer as a blank). The absorbance was determined at $475 \mathrm{~nm}$ using a Tecan Infinate Pro 200 plate reader.

Percentage inhibition of tyrosinase activity was determined using the following equation

$$
((1-B / A) \times 100)
$$

where $\mathrm{A}=$ change in optical density at $475 \mathrm{~nm}\left(\mathrm{OD}_{475}\right) /$ min without sample (negative controls) and $\mathrm{B}=$ change in $\mathrm{OD}_{475} / \mathrm{min}$ with sample. 


\section{Melanin determination in primary melanocytes treated with crude extracts and active compounds}

Primary melanocytes were seeded in 24-well plates at a density of $1 \times 10^{5}$ cells per well and following a 24 -h incubation were treated with crude extract ( 1 and $10 \mathrm{mg} / \mathrm{mL}$, compounds $\mathbf{1 , 5}$, and the positive control, $p$-hydroquinone (10 and $100 \mu \mathrm{M}$ each), DMSO, and $\mathrm{K}_{3} \mathrm{PO}_{4}$ buffer as negative controls and the media alone to serve as a blank.

Following 24-h and 48-h incubations, cells were rinsed with Dulbecco's PBS (Sigma-Aldrich) and removed from the base of the well using a cell scraper. Cells were pelleted in an Eppendorf tube and solubilized in a solution of $1 \mathrm{~N} \mathrm{NaOH}$ (Sigma-Aldrich) and $10 \%$ DMSO (>99.7\%, Sigma-Aldrich) and incubated at $80^{\circ} \mathrm{C}$ for $2 \mathrm{~h}$. Following this, cells were centrifuged at $12000 \mathrm{~g}$ for $10 \mathrm{~min}$ at room temperature, and the absorbance of $200 \mu \mathrm{L}$ of the supernatants was determined at $470 \mathrm{nM}$ using a Tecan Infinate Pro 200 plate reader. Melanin content of the supernatants was determined against a standard curve of synthetic melanin (synthetic, SigmaAldrich) $(0-20 \mathrm{ng} / \mathrm{mL})$ and was expressed as $\rho g /$ cell.

\section{Statistical analysis}

Cell viability, tyrosinase activity, and melanin content data are presented as mean \pm standard error of the mean (SEM) for 3 independent experiments $(n=3)$. Data were analyzed for significance ( $p \leq$ 0.05 ) using one-way analysis of variance; post hoc Tukey test was then used to compare the means.

\section{Acknowledgments}

A. F. Kamdem Waffo gratefully acknowledges a travel grant from the Royal Society.

\section{Conflict of Interest}

The authors declare there are no conflict of interest.

\section{References}

[1] Kanthraj GR. Skin-lightening agents: New chemical and plant extracts ongoing search for the holy grail!. Indian J Dermatol Venereol Leprol 2010; 76: 3-6

[2] Sheth VM, Pandya AG. Melasma: A comprehensive update: Part II. J Am Acad Dermatol 2011; 65: 699-714

[3] Olumide YM, Altraide D, Mohammed T, Ahamefule N, Ayanlowo S, Onyekonwu C, Essen N. Complications of chronic use of skin lightening cosmetics. Int J Dermatol 2008; 47: 344-353

[4] Findlay GH, Morrison JG, Simson IW. Exogenous ochronosis and pigmented colloid milium from hydroquinone bleaching creams. $\mathrm{Br}$ ] Dermatol 1975; 93: 613-622

[5] Findlay GH, de Beer HA. Chronic hydroquinone poisoning of the skin from skin-lightening cosmetics. A South African epidemic of ochronosis of the face in dark-skinned individuals. S Afr Med J 1980; 57: $187-190$

[6] Draelos ZD. Skin lightening preparations and the hydroquinone controversy. Dermatol Ther 2007; 20: 308-313
[7] Hardwick N, Van Gelder LW, Van der Merwe CA, Van der Merwe MP. Exogenous ochronosis: An epidemiological study. Br J Dermatol 1989; 120: $229-238$

[8] Mulholland DA, Mwangi EM, Dlova NC, Plant N, Crouch NR, Coombes P. Non-toxic melanin production inhibitors from Garcinia livingstonei (Clusiaceae). J Ethnopharmacol 2013; 149: 570-575

[9] Burkill HM. The Useful Plants of West Tropical Africa. vol. 4: Kew: Royal Botanic Gardens; 1985

[10] Lewis ]. Flora of Tropical East Africa. Kew: Royal Botanic Gardens 1956; 1

[11] Nkafamiya AJ, Manji AU, Umaru HA. Biochemical evaluation of Cassipourea congoensis (Tunti) and Nuclea latifolio (Luzzi) fruits. Afr J Biotech 2006; 6: 2461-2463

[12] Williams VL, Raimondo D, Crouch NR, Cunningham AB, Scott-Shaw CR, Lotter M, Ngwenya AM. Cassipourea malosana (Baker) Alston. National Assessment: Red List of South African Plants. Version. 2014. Accessed on July 2, 2015 http://redlist.sanbi.org/species.php?species=1580-27

[13] Kato A, Okada M, Hashimoto Y. Occurrence of gerrardine in Cassipourea guianensis. J Nat Prod 1984; 47: 706-707

[14] Kato A, Okada M, Hashimoto Y. Sulfur-containing alkaloids from Cassipourea guianensis. J Nat Prod 1985; 48: 289-292

[15] Ichimaru M, Kato A, Hashimoto Y. Cassipoureamide-A and -B: New sulfur-containing amides from stem wood of Cassipourea guianensis. J Nat Prod 2000; 63: 1675-1676

[16] Chaturvedala VSP, Norris A, Miller JS, Ratovoson F, Andriantsiferana R, Rasamison VE, Kingston DGI. Cytotoxic diterpenes from Cassipourea madagascariensis from the Madagascar rainforest. J Nat Prod 2006; 69: 287-289

[17] Hou Y, Cao S, Brodie PJ, Miller JS, Birkinshaw C, Andrianafy MN, Andriantsiferana R, Rasamison VE, Ten Dyke K, Shen Y, Suh MS, Kingston DGI. Euphane triterpenoids of Cassipourea lanceolata from the Madagascar rainforest. Phytochem 2010; 71: 669-674

[18] Drewes SE, Taylor CW, Cunningham AB. (+)-Afzelechin 3-rhamnoside from Cassipourea gerrardii. Phytochem 1992; 31: 1073-1075

[19] Drewes SE, Taylor CW, Cunningham AB, Ferreira D, Steenkamp JA. Epiafzelechin- $(4 \beta \rightarrow 8,2 \beta \rightarrow 0 \rightarrow 7)$-ent-afzelechin from Cassipourea gerrardii. Phytochem 1992; 31: 2491-2494

[20] Drewes SE, Taylor CW. Methylated A-type proanthocyanidins and related metabolites from Cassipourea gummiflua. Phytochem 1994; 37: 551-555

[21] Nishiyama Y, Noda Y, Nakatani N, Shitan N, Sudo T, Kato A, Chalo Mutiso PB. Structure of constituents isolated from the bark of Cassipourea malosana and their cytotoxicity against a human ovarian cell line. J Nat Med 2018; 73: 289-296

[22] Pupo MT, Vieira PC, Fernandes JB, Da Silva MFF. A cycloartane triterpenoid and $\dot{\omega}$-phenyl alkanoic and alkenoic acids from Trichilia claussenii. Phytochem 1996; 42: 795-798

[23] Anjaneyulu V, Satyanarayana P, Viswanadham KN, Jyothi VG, Nageswara R, Radhika P. Triterpenoids from Mangifera indica. Phytochem 1999; 50: 1229-1236

[24] Pillaiyar T, Manickam M, Namasivayam V. Skin whitening agents: Medicinal chemistry perspective of tyrosinase inhibitors. J Enzyme Inhib Med Chem 2017; 32: 403-425

[25] Chou ST, Chang WL, Chang CT, Hsu SL, Lin YC, Shih Y. Cinnamomum cassia essential oil inhibits $\alpha$-MSH-induced melanin production and oxidative stress in murine B16 melanoma cells. Int J Mol Sci 2013; 14: 19186-19201

[26] Palumbo A, d'Ischia M, Misuraca G, Prota G. Mechanism of inhibition of melanogenesis by hydroquinone. Biochim Biophys Acta 1991; 1073: 85-90 